\title{
PEMETAAN DAERAH RAWAN LONGSOR DENGAN METODE PENGINDERAAN JAUH DAN OPERASI BERBASIS SPASIAL, STUDI KASUS KOTA BATU JAWA TIMUR
}

\author{
Hana Sugiastu Firdaus, Bangun Muljo Sukojo, \\ Program Magister Teknik Geomatika, ITS \\ e-mail: hanasugiastufirdaus@gmail.com
}

\begin{abstract}
Abstrak. Jenis tanah pelapukan hasil letusan gunung api yang memiliki tingkat kesuburan tinggi terdapat di sebagian wilayah Indonesia. Komposisi tanah tersebut tersusun atas lempung dan sedikit pasir. Hal ini akan menimbulkan dampak negatif akan potensi tanah longsor jika tanah tersebut berada di atas batuan kedap air pada perbukitan dengan kemiringan sedang hingga terjal serta tidak ada tanaman keras berakar kuat. Fenomena tersebut dapat terjadi di daerah dengan topografi perbukitan seperti halnya di wilayah Kota Batu. Metode penginderaan jauh yang didasarkan pada citra satelit dapat digunakan untuk memetakan kawasan rawan longsor untuk wilayah yang relatif luas. Citra satelit menggambarkan reflektan dari objek di permukaan bumi yang di dalamnya terdiri dari komposisi beberapa band/kanal dengan rentang panjang gelombang tertentu. Komposit band dari citra digunakan untuk mempertajam objek sehingga memudahkan untuk melakukan klasifikasi tutupan lahan di permukaan bumi. Pemetaan zonasi area rawan longsor di Kota Batu didasarkan dari perhitungan bobot dan scoring tiap parameter longsor yang meliputi kondisi geologi, jenis tanah, curah hujan, tingkat kelerengan serta tutupan lahan hasil olahan citra satelit serta dilanjutkan dengan operasi spasial dari parameter tersebut. Hasil yang didapat menunjukan skor komulatif potensi tanah longsor di Kota Batu berkisar antara 1,55 - 3,65 yang didominasi oleh kategori rawan dengan luas area sekitar $125,97 \mathrm{~km}^{2}$. Pemetaan kawasan rawan longsor sangat diperlukan untuk membantu penetapan arahan kebijakan guna mengurangi dampak yang ditimbulkan akibat longsor.
\end{abstract}

Kata Kunci: tanah longsor, penginderaan jauh, operasi spasial, tutupan lahan, kemiringan lereng.

\begin{abstract}
The type of weathered soil as a result of volcanic eruptions that has a high fertility is located in some areas of Indonesia. The soil is composed by clay and little sand that will cause a negative impact such as landslide. Landslide can be occurred if the soil is above impermeable rocks in the moderate tilt hills or steep tilt hills and there are no strong rooted plants around the soil. That phenomenon can be occurred in hills area such as Batu Town. Remote sensing method which is based on satellite imagery can be used to map some landslide-potential areas. Satellite imagery shows the reflectance of objects in the earth's surface that contains various wavelength canals. Image's canal is used to sharpen the object so it will be easier to classify a land cover on the earth's surface. Landslide-potential area mapping in Batu Town is based on the weight and score calculation of landslide parameters such as geological condition, type of soil, rainfall, slope level, and land cover from satellite imagery processing and spatial operation. The result shows that cumulative score of landslide potential area in Batu Town is around $1.55-3.65$ or $125.97 \mathrm{~km}^{2}$. Landslide-potential area mapping is needed to decease the negative impact of landslide itself.
\end{abstract}

Keywords: landslide, remote sensing, spatial operation, land cover, slope.

\section{PENDAHULUAN}

Tingkat kerawanan tanah longsor di Kota Batu secara langsung dipengaruhi oleh kondisi bentang alamnya yang terdiri dari pegunungan dan perbukitan. Pegunungan tersebut meliputi Gunung Panderman (2010 m), Gunung Welirang (3156 m), Gunung Arjuno (3339 m), dan lain sebagainya. Selain itu, jenis tanahnya sebagian besar merupakan hasil mineral yang berasal dari ledakan gunung api dengan tingkat kesuburan yang tinggi. Pada dasarnya, peristiwa tanah longsor dapat diminimalisir jika tanah ditanami dengan tanaman yang memiliki akar yang kuat, mengingat fungsi tanaman sebagai penutup tanah dan pengikat agregat tanah jika dikenai oleh sebuah tekanan yang berasal dari curah hujan yang tinggi. Namun, dengan adanya perkembangan aktivitas manusia mengakibatkan beberapa perubahan fungsi lahan 
dari wilayah konservasi ke dalam wilayah budidaya maupun permukiman. Tanaman yang terdapat di kawasan budidaya tidak memiliki akar kuat untuk menahan tekanan dari curah hujan tinggi serta dengan adanya pembangunan permukiman yang tidak mengikuti kaidah konservasi dapat meningkatkan risiko dari tanah longsor.

Faktor yang menjadi penyebab terjadinya tanah longsor dapat diklasifikasikan menjadi dua yaitu dari aspek alam dan aspek manusia. Indikator dari aspek alam berdasarkan Peraturan Kementrian PU No.22/PRT/M/2007 tentang Pedoman Penataan Ruang Kawasan Rawan Bencana Longsor yang dikelompokkan menjadi 7 yaitu kemiringan lereng, kondisi tanah, batuan penyusun lereng, curah hujan, tata air lereng, kegempaan, dan vegetasi. Sedangkan aspek manusia yang dijadikan indikator penyebab tanah longsor adalah aktivitas manusia yang meliputi perubahan penggunaan lahan sehingga mempengaruhi bentang alam.

Parameter yang digunakan untuk memetakan daerah rawan longsor dalam penelitian ini terdiri dari aspek alam dan manusia yaitu berdasarkan kondisi geologi, kemiringan lereng, curah hujan, jenis tanah, dan tutupan lahan. Kondisi eksisting tutupan lahan didasarkan pada metode penginderaan jauh dengan pengolahan citra pasif Landsat 8 untuk tahun 2013. Selain itu, untuk mengetahui perubahan penggunaan lahan di area studi maka juga dilakukan klasifikasi tutupan lahan dengan citra pasif Landsat 7 ETM+ tahun 2006. Kemiringan lereng diekstrasi dari pengolahan citra Aster GDEM-2 dengan resolusi 17 meter. Untuk mendapatkan zonasi dari daerah rawan longsor di area studi, maka selanjutnya dilakukan metode scoring dan pembobotan dari parameter yang telah diolah.

Penelitian ini diharapkan dapat menghasilkan suatu zonasi kawasan yang rawan akan tanah longsor berdasarkan parameter aspek alam dan manusia di area studi dalam bentuk informasi spasial. Hasil yang didapat nantinya dapat menjadi bahan rujukan dan pertimbangan dalam menghasilkan arahan kebijakan dan rekomendasi terhadap pemerintah setempat untuk menangani kawasan rawan longsor di wilayah Kota Madya (Kodya) Batu.

\section{METODOLOGI \\ Data}

Data yang digunakan dalam penelitian ini yaitu:

1. Citra Satelit Landsat 7 ETM+ path/row 118/65 tahun 2006 (USGS).

2. Citra Satelit Landsat 8 path/row $118 / 65$ tahun 2013 (USGS).

3. Data ASTER GDEM level 2 dengan resolusi 17 meter.

4. Peta Digital Rupa Bumi Indonesia (RBI) wilayah Kodya Batu skala 1:25.000.

5. Data Curah Hujan dari stasiun BMKG di Kota Batu tahun 2012-2013.

6. Peta Jenis Tanah skala 1:25.000 (Bappeda Kota Batu).

7. Peta Geologi Regional Jawa Timur Lembar Kota Batu Skala 1:100.000 tahun 1992 (Pusat Penelitian dan Pengembangan Geologi).

8. Peta Geologi Lingkungan Malang Skala 1:100.000 (Direktorat Geologi Tata Lingkungan, Bandung).

\section{Penginderaan Jauh}

Penginderaan jauh adalah ilmu atau seni untuk memperoleh informasi tentang objek, daerah, atau gejala, dengan jalan menganalisis data yang diperoleh dengan menggunakan alat, tanpa kontak langsung dengan objek, daerah, atau gejala yang akan dikaji (Lillesan dkk.,2004). Karakter utama dari suatu image (citra) dalam penginderaan jauh adalah adanya rentang panjang gelombang (wavelength band) yang dimilikinya. Dalam penelitian ini, citra yang digunakan menggunakan sistem pasif yang memanfaatkan energi alamiah yaitu energi matahari untuk mendapatkan gambaran objek di permukan bumi.

\section{Supervised Classification}

Metode ini digunakan untuk mendapatkan penggunaan lahan di area studi yang didasarkan 
pada proses klasifikasi nilai piksel pada contoh daerah yang diketahui jenis objek dan nilai spektralnya, yaitu apabila objek di permukaan bumi tersebut telah dikenal oleh pengamat/penilai baik secara langsung di lapangan atau didapatkan dari data sekunder/statistik (peta, Tabel, laporan, dan sebagainya). Dalam klasifikasi ini digunakan citra multispektral yang berbasis numerik, dan untuk pengenalan polanya didasarkan pada perhitungan maximum likelihood. Hasil tutupan lahan yang didapat selanjutnya dilakukan uji ketelitian untuk mengetahui tingkat keakuratan klasifikasi dengan kondisi di lapangan. Perhitungan ketelitian dilakukan dengan menggunakan confusion matrix dari sampel data hasil klasifikasi dan tutupan lahan di lapangan.

Ketelitian pemetaan dibuat dalam beberapa kelas $\mathrm{X}$ yang dihitung dengan persamaan:

$$
M A=\frac{\mathrm{X}_{\text {cr }} \text { pixel }}{\mathrm{X}_{\text {cr }} \text { pixel }+\mathrm{X}_{\mathrm{o}} \text { pixel }+\mathrm{X}_{\text {co }} \text { pixel }}
$$

\section{Keterangan :}

$\mathrm{MA}=$ Ketelitian pemetaan (mapping accuracy

$\mathrm{Xcr}=$ Jumlah kelas $\mathrm{X}$ yang terkoreksi

Xo $=$ Jumlah kelas $X$ yang masuk ke kelas lain (omisi)

Xco = Jumlah kelas $\mathrm{X}$ tambahan dari kelas lain (komisi)

\section{Pembobotan dan Scoring}

Pemberian bobot untuk parameter didasarkan pada sifat faktor itu sendiri, dimana faktor dinamis diberi bobot nilai lebih tinggi dikarenakan kejadian longsoran selalu dipicu oleh adanya perubahan gaya sebagai bentuk akibat dari perubahan faktor yang bersifat dinamis. Indikator faktor dinamis untuk curah hujan diberikan bobot yang lebih besar daripada penggunaan lahan. Hal ini didasarkan karena perubahan massa batuan dan tanah lebih cepat berubah dalam jumlah besar akibat terkena tingginya tekanan dari curah hujan. Perhitungan skor kumulatif pada penelitian ini, didasarkan pada Direktorat Vulkanologi dan Mitigasi Bencana dengan rumus pembobotan yang digunakan adalah sebagai berikut :
Skor $=(30 \% \times$ faktor kelas curah hujan $)$

$+(20 \% \times$ faktor kelas geologi)

$+(20 \% \times$ faktor kelas jenis tanah) $+(15 \% \times$ faktor kelas penggunaan lahan $)+(15 \% x$ faktor kelas lereng)

Skor kumulatif yang diperoleh, nantinya dikelompokkan menjadi tiga kelas, dengan kategori sebagai berikut:

1. Kurang Rawan $(\leq 2,5)$

2. Rawan ( $(\geq 2,6 \mathrm{~s} / \mathrm{d} \leq 3,6)$

3. Sangat Rawan $(\geq 3,7)$

\section{Spatial Analysis}

Metode ini merupakan operasi berbasis spasial yang terdiri dari beberapa operasi yang digunakan pada layer spasial. Penelitian ini menggunakan beberapa operasi seperti (1) reclassify (mengklasifikasikan kembali suatu data hingga menjadi data spasial baru berdasarkan kriteria (atribut) tertentu; (2) overlay (fungsionalitas ini menghasilkan layer data spasial baru yang merupakan hasil kombinasi dari minimal dua layer yang menjadi masukannya); (3) 3D Analysis dan Surface Analysis (terdiri dari sub-sub fungsi yang terkait dengan presentasi data spasial di dalam ruang 3 dimensi (permukaan digital) maupun 2 dimensi, serta beberapa operasi spasial yang lainnya) (Prahasata, 2009).

\section{HASIL DAN PEMBAHASAN}

Penentuan zonasi kawasan rawan longsor di Kota Batu didasarkan pada beberapa parameter yang akan dijelaskan sebagai berikut.

\section{Curah Hujan}

Curah hujan yang terdapat di area studi didasarkan pada pengolahan data pengamatan delapan stasiun BMKG di Kota Batu untuk kurun waktu tahun 2012-2013. Peta curah hujan dihasilkan dengan menggambar dulu kontur tinggi hujan yang sama (isohyet). Kemudian luas bagian diantara isohyet-isohyet yang berdekatan diukur, 
dan nilai rata-rata dihitung sebagai nilai rata-rata timbang nilai kontur, kemudian dikalikan dengan masing-masing luasnya. Hasilnya dijumlahkan dan dibagi dengan luas total daerah, sehingga akan didapat curah hujan areal yang dicari (Soemarto,1999).

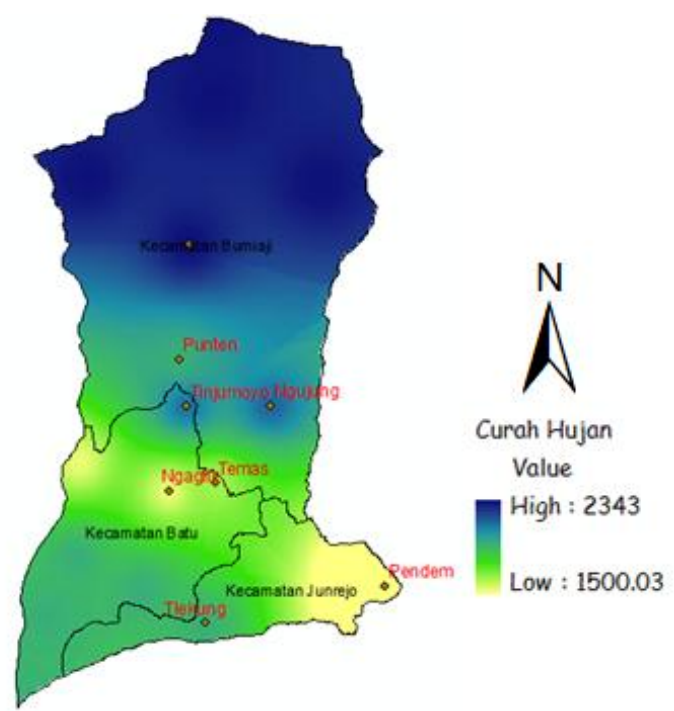

Gambar 1. Curah Hujan di Kota Batu Tahun 2012-2013

Hasil yang didapat dari pengolahan tersebut dapat dilihat pada Gambar 1.

Curah hujan rata-rata Kota Batu selama kurun waktu 2012-2013 berkisar antara 1500-2343 $\mathrm{mm} /$ tahun. Kisaran nilai curah hujan tersebut menunjukkan Kota Batu mempunyai tipe iklim sedang dengan curah hujan yang tertinggi terdapat di sebelah utara di Kecamatan Bumiaji.

\section{Kondisi Geologi}

Berdasarkan peta geologi skala 1:100.000, sebagian besar wilayah Kota Batu tersusun atas batuan vulkanik yang berasal dari gunung berapi. Batuan vulkanik yang terdapat di Kota Batu antara lain:

Batuan Gunung Api Anjasmara Tua (Qpat) yang merupakan endapan piroklastika yang tertua dan diperkirakan berumur Plistosen Awal hingga Tengah, umumnya sudah pejal dan termampatkan, tersusun dari andesit hingga basal, dan sebagian terubah. Satuan ini tersingkap sempit di bagian barat Kota Batu.
Batuan Gunung Api Anjasmara Muda (Qpva) merupakan endapan piroklastika yang tersusun dari andesit piroksen dan basal olivin, umumnya agak padu dan mampat, yang diperkirakan berumur Plistosen Tengah. Satuan ini terletak di sebelah utara dari batuan Qpat.

Batuan Gunung Api Kawi-Butak (Qpkb) merupakan endapan piroklastika bersifat menengah hingga agak basa; tersusun dari andesit, basal, dan batuan porfiri; sebagian telah berubah dan mengalami pemampatan yang cukup kuat; dan umurnya diperkirakan Plistosen Tengah sampai Plistosen Akhir bagian awal. Satuan ini terdapat di bagian selatan Kota Batu.

Batuan Gunung Api Arjuna - Welirang (Qvaw) di sebelah timur Kota Batu diduga berumur Plistosen Akhir dan tersusun dari breksi, tuf, lava, aglomerat, dan lahar.

\section{Jenis Tanah}

Jenis tanah yang terdapat di area studi terdiri dari tiga jenis tanah yaitu andosol, grumosol, dan mediteran. Sebaran ketiga jenis tanah tersebut dapat dilihat pada Gambar 2. Sebagian besar Kota Batu memiliki tipe tanah grumosol dengan luas $\pm 122,46 \mathrm{~km}^{2}$. Untuk tipe tanah andosol dan mediteran masing-masing memiliki luasan $\pm 18,32$ $\mathrm{km}^{2}$ dan $58,15 \mathrm{~km}^{2}$.

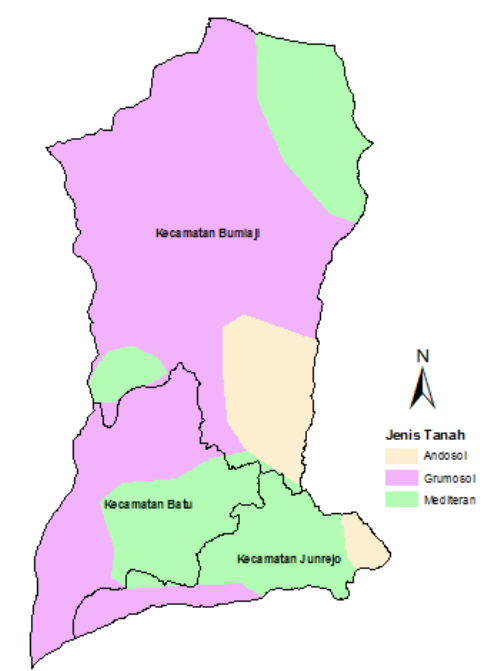

Gambar 2. Jenis Tanah di Kota Batu 


\section{Kemiringan Lereng}

Derajat kemiringan lereng di area studi diekstrasi dari pengolahan citra Aster GDEM-2 dengan resolusi 17 meter. Berdasarkan data DEM, Kota Batu memiliki ketinggian berkisar antara 5733250 mdpl. Selanjutnya DEM tersebut diolah untuk mendapatkan kemiringan lereng (slope) dari nilainilai piksel di DEM dengan menggunakan operasi spasial sehingga didapatkan kemiringan lereng seperti pada Gambar 3.
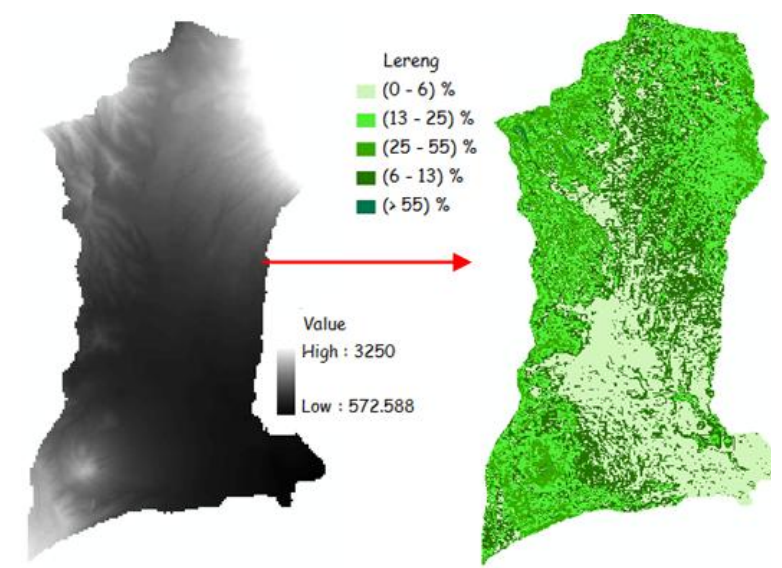

Gambar 3. Hasil Kemiringan Lereng di Kota Batu dari Pengolahan Aster GDEM-2

\section{Tutupan Lahan}

Sebelum mengklasifikasikan tutupan lahan di area studi, citra Landsat 8 tahun 2013 dilakukan pengkoreksian terlebih dahulu baik koreksi radiometrik dan koreksi geometrik. Koreksi radiometrik merupakan proses untuk meniadakan ganguan (noise) yang terjadi akibat pengaruh atmosferik maupun karena pengaruh sistematik perekaman citra. Sedangkan koreksi geometrik merupakan koreksi untuk mendapatkan koordinat citra sesuai dengan koordinat sistem proyeksi tertentu yang merepresentasikan koordinat sebenarnya di lapangan. Oleh karena itu koreksi geometrik dilakukan dengan proses transformasi yang dapat ditetapkan melalui hubungan sistem koordinat citra $(u, v)$ dan sistem koordinat geografi $(x, y)$. Perhitungan RMS (Root Mean Square) dilakukan untuk mengetahui kesalahan koreksi. Nilai RMS yang dihasilkan untuk citra Landsat 8 tahun 2013 yaitu 0,043 . Syarat toleransi nilai RMS kurang atau sama dengan satu (RMS $\leqslant 1$ ). Selanjutnya dilakukan pemotongan atau subseting area studi dan supervised classification. Peta dasar yang digunakan sebagai acuan klasifikasi tutupan lahan adalah Peta RBI Kota Batu skala 1:25.000 dan kenampakan di lapangan. Hasil klasifikasi tutupan lahan untuk tahun 2013 di Kota Batu dapat dilihat pada Gambar 3. Sedangkan luas area untuk masingmasing tutupan lahan dapat dilihat pada Tabel 1. Ketelitian klasifikasi tutupan lahan dengan menggunakan confussion matrix didapatkan nilai keakuratan $93,62 \%$.

\section{Pembobotan dan Scoring Parameter}

Parameter baik dari aspek alam dan manusia yang telah diolah selanjutnya dilakukan pengkelasan sesuai dengan kriteria pemicu terjadinya longsor. Skor yang diberikan untuk masing-masing parameter dapat dilihat pada Tabel 2. Skor yang diberikan memiliki rentang nilai 1 sampai 5 . Skor yang dimiliki oleh masing-masing parameter selanjutnya dikalikan dengan bobot untuk tiap parameter berdasarkan (persamaan 2) untuk mendapatkan skor kumulatif dari semua parameter. Diperlukan integrasi untuk keseluruhan parameter yang didapat dari overlay layer spasial tiap parameter.

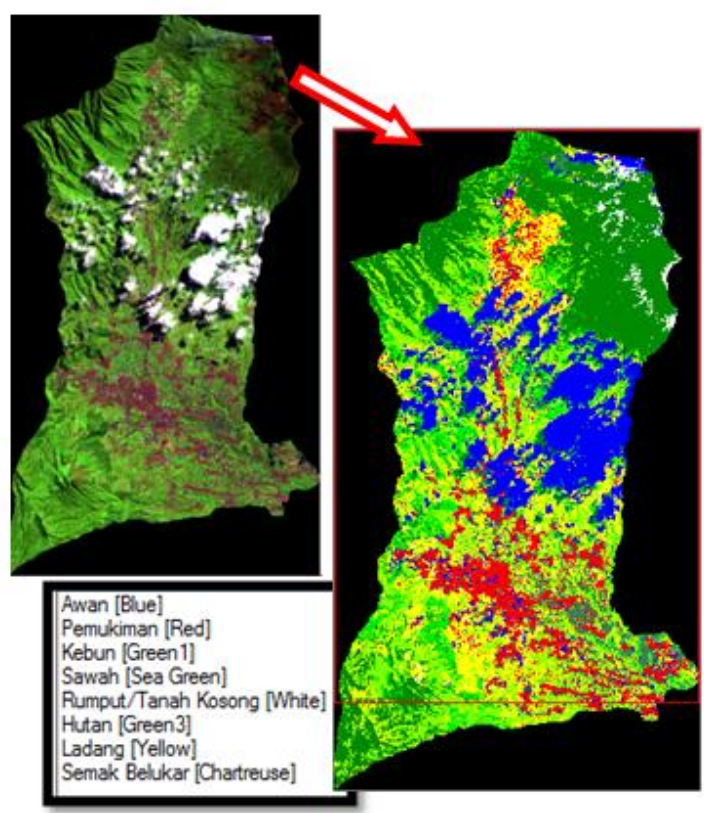

Gambar 4. Hasil Tutupan Lahan Kota Batu Tahun 2013 
Tabel 1. Luas Tutupan Lahan di Kota Batu Tahun 2013 dari Hasil Pengolahan Citra Landsat 8

\begin{tabular}{|c|c|c|}
\hline Tutupan Lahan & $\begin{array}{c}\text { Luas } \\
\mathbf{( k m}^{\mathbf{2}} \mathbf{)}\end{array}$ & Prosen (\%) \\
\hline Hutan & 48,26 & 28,67 \\
\hline Semak Belukar & 37,04 & 22,00 \\
\hline Ladang & 34,73 & 20,63 \\
\hline Kebun & 14,93 & 8,87 \\
\hline Sawah & 12,40 & 7,36 \\
\hline Rumput/Tanah & 3,31 & 1,97 \\
\hline Kosong & 1,69 & 10,51 \\
\hline Pemukiman & $\mathbf{1 6 8 , 3 5}$ & $\mathbf{1 0 0}$ \\
\hline Total
\end{tabular}

Sumber: Hasil Pengolahan Citra Landsat 8 Tahun 2013

Tabel 2. Nilai Skor dari Parameter Longsor

\begin{tabular}{|c|c|c|c|}
\hline No & Parameter & Besaran & Skor \\
\hline \multirow{5}{*}{1.} & \multirow{5}{*}{$\begin{array}{c}\text { Kelerengan } \\
\text { berdasarkan } \\
\text { USSSM } \\
\text { (United Stated } \\
\text { Soil System } \\
\text { Management) }\end{array}$} & $>55 \%$ & 5 \\
\hline & & $25-55 \%$ & 4 \\
\hline & & $13-25 \%$ & 3 \\
\hline & & $6-13 \%$ & 2 \\
\hline & & $0-6 \%$ & 1 \\
\hline \multirow{5}{*}{2.} & \multirow{5}{*}{$\begin{array}{l}\text { Curah Hujan } \\
\text { Bulanan } \\
\text { (mm/tahun) } \\
{[3]}\end{array}$} & $>3.000$ & 5 \\
\hline & & $2.500-3.000$ & 4 \\
\hline & & $2.000-2.500$ & 3 \\
\hline & & $1.000-2.000$ & 2 \\
\hline & & $<1.000$ & 1 \\
\hline \multirow{5}{*}{3.} & \multirow{5}{*}{$\begin{array}{c}\text { Jenis Tanah } \\
\text { [2] }\end{array}$} & $\begin{array}{l}\text { Regosol, Litosol, } \\
\text { Renzina }\end{array}$ & 5 \\
\hline & & $\begin{array}{c}\text { Andosol, Laterik, } \\
\text { Grumosol, Podsol, } \\
\text { Podsolik }\end{array}$ & 4 \\
\hline & & $\begin{array}{l}\text { Brown forest soil, } \\
\text { Non calcik brown, } \\
\text { Mideteranian }\end{array}$ & 3 \\
\hline & & Latosol & 2 \\
\hline & & $\begin{array}{l}\text { Aluvial, Gleisol, } \\
\text { Planosol, } \\
\text { Hidromorf kelabu, } \\
\text { Laterik air tanah }\end{array}$ & 1 \\
\hline
\end{tabular}

\begin{tabular}{|c|c|c|c|}
\hline \multirow{5}{*}{4.} & \multirow{5}{*}{$\begin{array}{l}\text { Penggunaan } \\
\text { Lahan } \\
{[3]}\end{array}$} & $\begin{array}{l}\text { Lahan-lahan } \\
\text { kosong }\end{array}$ & 5 \\
\hline & & $\begin{array}{l}\text { Kawasan industri } \\
\text { dan permukiman }\end{array}$ & 4 \\
\hline & & $\begin{array}{c}\text { Perkebunan dan } \\
\text { sawah irigasi }\end{array}$ & 3 \\
\hline & & $\begin{array}{c}\text { Kebun } \\
\text { campuran/semak } \\
\text { belukar }\end{array}$ & 2 \\
\hline & & $\begin{array}{l}\text { Hutan/vegetasi } \\
\text { lebat dan badan- } \\
\text { badan air }\end{array}$ & 1 \\
\hline \multirow{4}{*}{5.} & \multirow{4}{*}{$\begin{array}{c}\text { Faktor } \\
\text { Geologi (Jenis } \\
\text { Batuan) } \\
{[3]}\end{array}$} & $\begin{array}{c}\text { Bahan sedimen-2 } \\
\text { dan vulkanik-2 }\end{array}$ & 4 \\
\hline & & Bahan sedimen-1 & 3 \\
\hline & & Bahan vulkanik-1 & 2 \\
\hline & & Bahan aluvial & 1 \\
\hline
\end{tabular}

\section{Zonasi Daerah Rawan Longsor}

Penentuan tingkat kerawanan daerah longsor didasarkan dari hasil skor komulatif yang didapat dari keseluruhan parameter. Skor komulatif yang dihasilkan mempunyai rentang nilai antara 1,55 3,65 dan didominasi oleh kategori rawan dengan luas area $\pm 125,97 \mathrm{~km}^{2}$. Sedangkan untuk kategori kurang rawan memiliki luas area $\pm 81,95 \mathrm{~km}^{2}$ dan kategori sangat rawan dengan luas area $\pm 697,68$ $\mathrm{m}^{2}$. Adapun persebaran daerah rawan longsor di Kota Batu dapat dilihat pada lampiran 1. Hasil yang didapat selanjutnya dibandingkan dengan Peta Geologi Lingkungan skala 1:100.000, dimana dalam peta tersebut menunjukan Kota Batu memiliki tingkat longsor dengan kategori zona kerentanan pergerakan tanah (tanah longsor) menengah dan terdapat beberapa lokasi yang termasuk dalam daerah waspada letusan gunung berapi. Hal ini sesuai dengan hasil pengolahan dari penelitian ini yaitu Kota Batu didominasi oleh longsor dengan kategori rawan. Erosi bersifat lateral terutama pada daerah bervegetasi jarang, sedang erosi berkelas rendah-sedang terdapat pada tebing sungai, selain itu termasuk dalam daerah waspada bahaya gunung api (awan panas, debu vulkanik, bom, lapilli, serta gempa Gunung Welirang dan Arjuno. Sebaran zona rawan pergerakan tanah berdasarkan Peta Geologi Lingkungan dapat dilihat pada Gambar 5. 


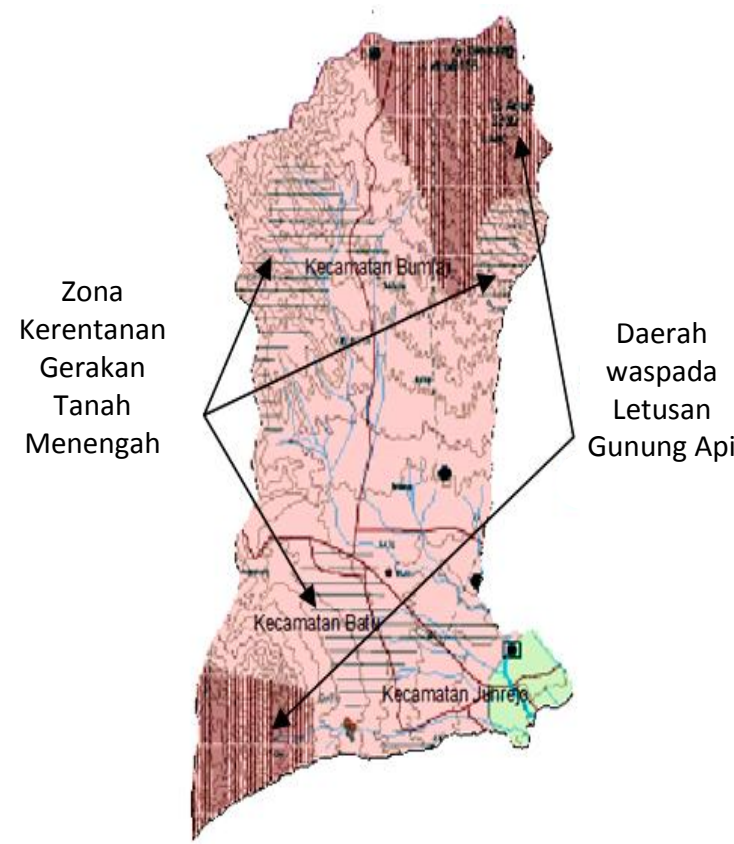

Gambar 5. Zona Kerentanan Gerakan Tanah dan Daerah Waspada Letusan Gunung Api di Kota Batu (Sumber: Peta Geologi Lingkungan Lembar Malang Skala 1:100.000, 1992)

Sebaran zonasi daerah rawan longsor dalam penelitian ini menunjukkan hasil yang mendekati sama dengan Peta Geologi Lingkungan, walaupun ada perbedan untuk zona gerakan tanah menengah di bagian tengah Kota Batu. Dimana hasil pengolahan yang didapat menunjukkan bagian tengah Kota Batu memiliki kategori kurang rawan terjadinya longsor. Kategori rawan longsor yang memiliki skor tinggi (skor kumulatif $>3$ ) dalam penelitian ini terdapat di sebelah timur laut Kota Batu di Kecamatan Bumiaji dengan arah kemiringan lereng yang mengarah ke barat daya serta di sebelah barat daya Kota Batu di Kecamatan Junrejo dan Kecamatan Batu dengan arah kemiringan lereng ke timur laut. Adapun arah kemiringan lereng untuk daerah rawan longsor di Kota Batu dapat dilihat pada Gambar 6. Arah kemiringan lereng yang diperoleh dari data Aster GDEM-2 yang didasarkan pada nilai maksimum perubahan nilai dari setiap sel tetangganya. Nilai-nilai output raster akan menjadi arah kompas untuk menunjukkan kemiringan lereng. Secara konseptual, nilai kemiringan lereng menunjukkan nilai $\mathrm{z}$ dari nilai tetangga kernel window $3 \times 3$ disekitar pengolahan atau pusat sel dari citra.

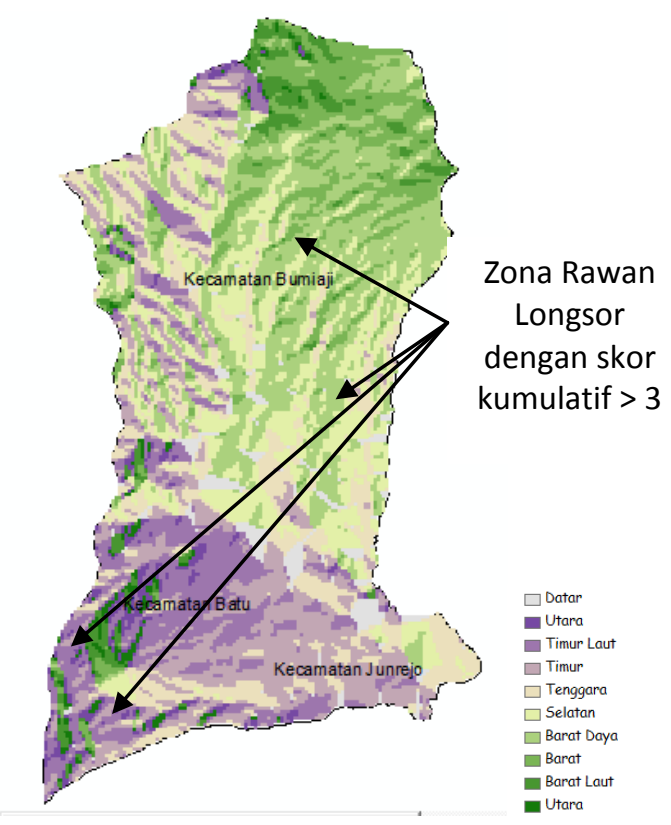

Gambar 6. Arah Kemiringan Lereng dari Zona Daerah Rawan Longsor yang Memiliki Nilai Skor Kumulatif $>3$

\section{Perubahan Penggunaan Lahan di Zona Rawan Longsor Kota Batu}

Berdasarkan hasil pengolahan citra Landsat 7 ETM+ untuk tahun 2006 dan Landsat 8 tahun 2013 dapat diketahui perubahan penggunaan lahan di Kota Batu khususnya untuk daerah yang rawan akan longsor. Ketelitian klasifikasi untuk citra tahun 2006 sebesar 92,21\% sedangkan untuk tahun 2013 sebesar 93,62 \%. Pada Gambar 7 dapat dilihat perbandingan penggunaan lahan untuk tahun 2006 dan 2013. Awan dan bayangan awan (warna biru) pada citra tahun 2013 lebih banyak menutupi area studi dibandingkan dengan tahun 2006. Dimana prosentase untuk tahun 2006 sebesar 0,033\% sedangkan untuk tahun 2013 sebesar 9,649\%. Awan tersebut menutupi tutupan lahan yang sebenarnya, berdasarkan hasil pengolahan citra tahun 2006, tutupan lahan yang terbayangi oleh awan untuk tahun 2013 berupa daerah perkebunan sehingga luas area perkebunan untuk tahun 2013 tidak menunjukkan hasil yang sesungguhya. Adapun 
perubahan luas penggunaan lahan antara tahun 2006-2013 dapat dilihat pada Tabel 3.

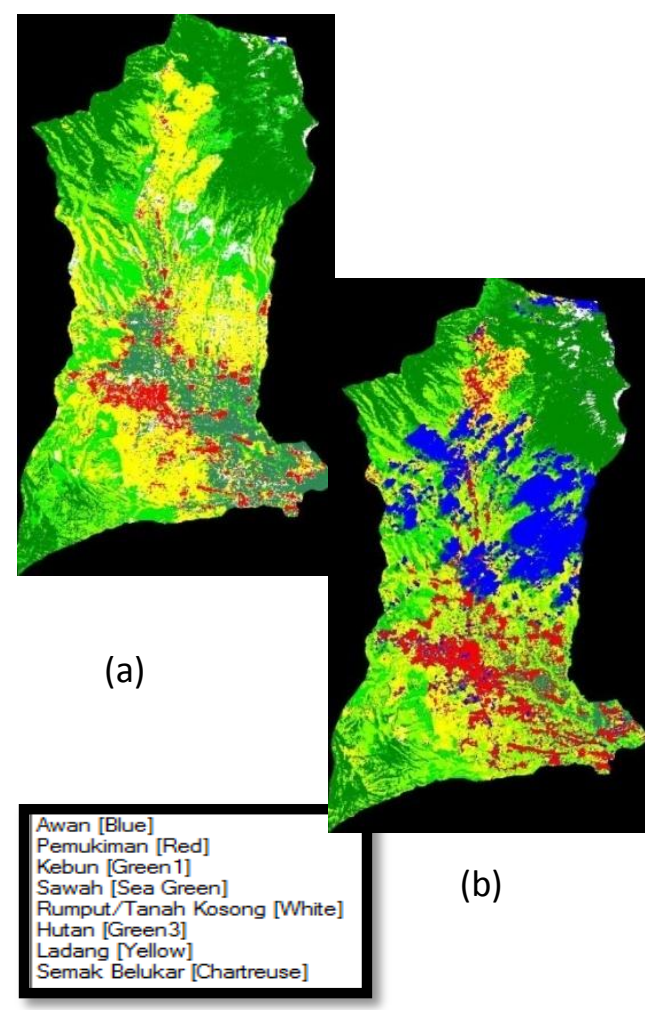

Gambar 7. (a) Hasil Klasifikasi Tutupan Lahan Tahun 2006, (b) Hasil Klasifikasi Tutupan Lahan Tahun 2013

Tabel 3. Penggunaan Lahan Kota Batu Tahun 2006 dan 2013 berdasarkan Pengolahan Citra Landsat

\begin{tabular}{|c|r|r|r|r|}
\hline \multirow{2}{*}{$\begin{array}{c}\text { Jenis Tutupan } \\
\text { Lahan }\end{array}$} & \multicolumn{2}{|c|}{$\begin{array}{c}\text { Luas Area } \\
\left(\mathbf{k m}^{\mathbf{2}}\right)\end{array}$} & \multirow{2}{*}{ Selisih } & \multirow{2}{*}{ Ket. } \\
\cline { 2 - 4 } & $\mathbf{2 0 0 6}$ & $\mathbf{2 0 1 3}$ & & \\
\hline Hutan & 50,88 & 48,26 & 2,62 & $(-)$ \\
\hline Semak Belukar & 16,56 & 37,04 & 20,48 & $(+)$ \\
\hline Ladang & 51,33 & 34,73 & 16,60 & $(-)$ \\
\hline Kebun & 32,43 & 14,93 & 17,50 & $(-)$ \\
\hline Sawah & 23,59 & 12,40 & 11,20 & $(-)$ \\
\hline $\begin{array}{c}\text { Rumput/Tanah } \\
\text { Kosong }\end{array}$ & 14,01 & 3,31 & 10,70 & $(-)$ \\
\hline Pemukiman & 10,26 & 17,69 & 7,43 & $(+)$ \\
\hline
\end{tabular}

Keterangan:
$(-)$ = Berkurang
$(+)=$ Bertambah
Sumber: Hasil Pengolahan Citra

Berdasarkan Tabel 3 tutupan lahan yang mengalami penurunan jumlah luasan yaitu hutan, ladang, kebun, sawah, dan rumput tanah kosong, sedangkan yang bertambah yaitu semak belukar dan permukiman. Luas area perkebunan dan ladang untuk tahun 2013 tidak dapat dijadikan acuan pasti karena ada bayangan awan yang meliputi tutupan lahan tersebut. Namun pada kenyataan lapangan perkebunan dan ladang tetap mengalami penurunan walaupun tidak signifikan, seiring dengan kebutuhan akan manusia akan hunian. Untuk penurunan luas area sawah dan pertambahan permukiman dapat dilihat secara lebih jelas pada Gambar 7 yang terpusat di tengah Kota Batu.

Berdasarkan penggunaan lahan tahun 2006 dan 2013 serta zonasi daerah rawan longsor, maka dapat dianalisis perubahan penggunaan lahan di daerah rawan longsor tersebut. Perubahan penggunaan lahan antara tahun 2006 - 2013 yang terdapat di daerah rawan longsor dengan skor komulatif > 3 antara lain, yaitu:

1. Hutan menjadi permukiman, kebun, sawah, rumput/tanah kosong, dan ladang.

2. Kebun menjadi rumput/tanah kosong, semak belukar, dan pemukiman.

3. Ladang menjadi rumput/tanah kosong dan pemukiman.

4. Sawah menjadi permukiman

\section{PENUTUP}

\section{Simpulan}

Simpulan Pemetaan zona rawan longsor dapat dihitung berdasarkan integrasi spasial dari parameter-parameter yang mempengaruhi dan memicu longsor. Untuk mendapatkan parameter yang dibutuhkan dapat menggunakan metode penginderaan jauh yang didasarkan dari pengolahan citra, dalam penelitian ini menggunakan citra Landsat. Hasil pengolahan yang didapat menunjukkan zona daerah rawan longsor di Kota Batu termasuk dalam kategori kurang rawan sampai sangat rawan $(1,55-3,65)$. Kategori rawan dengan luas area $\pm 125,97 \mathrm{~km}^{2}$. Zona rawan dengan skor kumulatif tinggi (> 3) di Kota Batu dalam penelitian ini terdapat di sebelah timur laut Kota Batu di Kecamatan Bumiaji dengan arah kemiringan lereng yang mengarah ke barat daya serta di sebelah barat daya Kota Batu di Kecamatan Junrejo dan 
Kecamatan Batu dengan arah kemiringan lereng ke timur laut.

Selain itu, terdapat perubahan wilayah konservasi menjadi wilayah budidaya maupun kawasan hunian untuk kurun waktu 2006-2013 di zona tersebut. Hal ini ditandai dengan adanya perubahan wilayah konservasi ke wilayah budidaya (hutan menjadi kebun, sawah, ladang, dan pemukiman) maupun wilayah budidaya ke kawasan hunian (kebun, ladang, dan sawah menjadi daerah pemukiman). Hasil yang didapat selanjutnya dapat dijadikan masukan pemerintah setempat untuk penataan pembangun kota agar tidak berada di kawasan rawan longsor. Sehingga, diharapkan kerugian akan longsor dapat diminimalisir dan perlindungan kawasan rawan longsor dapat dilakukan. Hasil pemetaan zona rawan longsor akan lebih teliti jika citra yang diolah memiliki bayangan awan yang sedikit.

\section{DAFTAR PUSTAKA}

Departemen Manajemen Hutan, 2008. Fakultas Kehutanan. Institut Pertanian Bogor.

Direktorat Vulkanologi dan Mitigasi Bencana Geologi, 2004. Model Perhitungan Skor Kawasan Rawan Tanah Longsor, Bandung.

Effendi, R. S, 2002. Pengendalian Erosi Tanah Dalam Rangka Pelestarian Lingkungan Hidup. Jakarta: Bumi Aksara.

Lestari, F.F., 2008. Penerapan Sistem Informasi Geografis dalam Pemetaan Daerah Rawan Longsor di Kabupaten Bogor. Bogor.

Lillesand, T.M., Kiefer, R.W., Chipman J.W, 2004. Remote Sensing and Image Interpretation. Fifth Edition, New York : John Wiley \& Sons.

Peraturan Menteri Pekerjaan Umum No.22/PRT/M/2007 Tentang Pedoman Penataan Ruang Kawasan Rawan Bencana Longsor, Jakarta.
Prahasta, Eddy, 2009. Sistem Informasi Geografis (Konsep-Konsep Dasar Perspektif Geodesi Dan Geomatika. Bandung: Informatika Bandung.

Soemarto, C.D, 1999. Hidrologi Teknik. Jakarta: Erlangga. 


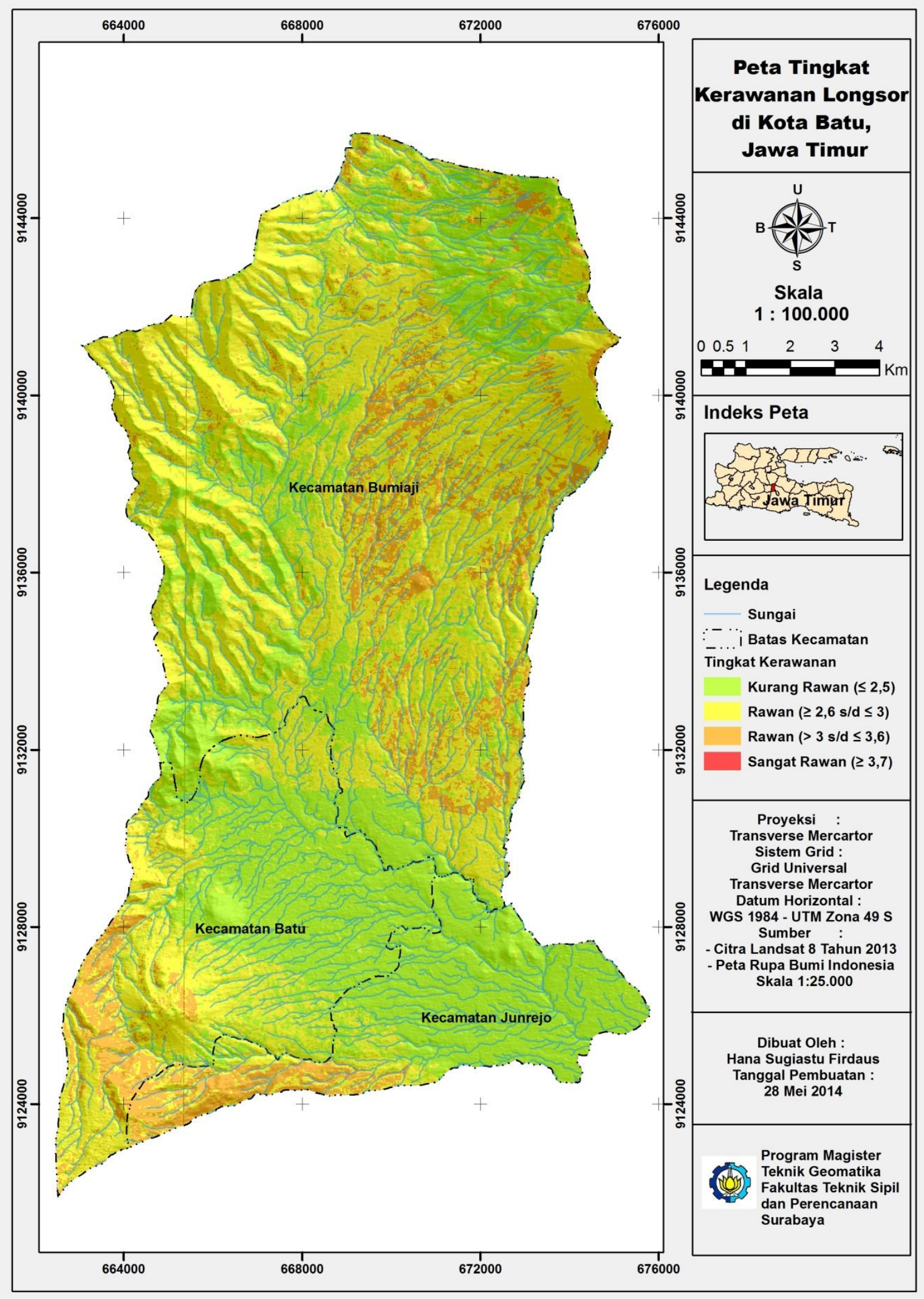

